\title{
Protection against the Lethal Effects of Pentobarbital in Mice by a Benzodiazepine Receptor Inverse Agonist, 6,7-Dimethoxy-4-Ethyl-3-Carbomethoxy- $\beta$-Carboline
}

\author{
H. Havoundjian, ${ }^{\star \star}$ G. F. Reed, 5 S. M. Paul," and P. Skolnick* \\ ${ }^{*}$ Laboratory of Bioorganic Chemistry, National Institute of Diabetes and Digestive and Kidney Diseases; ${ }^{\ddagger}$ Howard Hughes Medical \\ Institute, ${ }^{\S}$ Biometry Branch, National Institute of Child Health and Human Development; and "Clinical Neuroscience Branch, \\ National Institute of Mental Health, National Institutes of Health, Bethesda, Maryland 20892
}

\begin{abstract}
The benzodiazepine receptor inverse agonist 6,7-dimethoxy-4ethyl-3-carbomethoxy- $\beta$-carboline (DMCM) $(1.5-15 \mathrm{mg} / \mathrm{kg}$ ) was administered to mice $5 \mathrm{~min}$ after a lethal $\left(\mathbf{L D}_{94}\right)$ injection of pentobarbital. DMCM (1.5-5 mg/kg) increased short-term (1 h) survival in a dose-dependent fashion, with an optimum survival rate more than five times greater than mice receiving pentobarbital alone. Statistically significant increases in longterm ( $24 \mathrm{~h}$ ) survival were also observed after both 5 and $10 \mathrm{mg} /$ kg of DMCM (34 and 33\%, respectively) compared with animals receiving pentobarbital alone (6\%). Two doses of DMCM (5 and $2.5 \mathrm{mg} / \mathrm{kg}$, respectively) administered $55 \mathrm{~min}$ apart produced an even greater increase (58\%) in 24-h survival rates. Doses of DMCM that increased 1- and 24-h survival were not lethal when administered alone, and were below the dose that produced convulsions in $50 \%\left(C D_{50}\right)$ of the animals. The protective effects of DMCM were blocked by pretreatment with the benzodiazepine receptor antagonist ethyl-8-fluoro-5,6-dihydro-5-methyl-6-oxo4H-imidazo[1,5a][1,4]benzodiazodiazepine-3-carboxylate (Ro 151788), which suggests the effects of DMCM are mediated through the benzodiazepine receptor. These findings suggest that DMCM or another benzodiazepine receptor ligand with full inverse agonist qualities could prove effective as an antidote for barbiturate intoxication in man.
\end{abstract}

\section{Introduction}

Ingestion of 2-6 $\mathrm{g}$ of a short-acting barbiturate (e.g., pentobarbital) is fatal in $0.5-12 \%$ of cases $(1,2)$, with an annual mortality rate in the United States and United Kingdom of $\sim 1,600$ (3). Thus, barbiturate poisoning, whether intentional or accidental, remains a significant clinical problem. Current management of severe barbiturate intoxication consists of supportive measures (maintenance of respiration and cardiovascular tone) coupled with procedures to increase drug elimination (peritoneal dialysis, hemodialysis, and hemoperfusion) (3). In the past, barbiturate poisoning had been treated with agents such as picrotoxin and pentylenetetrazole. However, the use of these compounds was discontinued (4) due to their toxicity and equivocal efficacy.

Address correspondence to Dr. Skolnick, Chief, Section on Neurobiology, NIDDK/LBC, National Institutes of Health, Building 8, Room 103, Bethesda, MD 20892. 1986.

Received for publication 16 May 1986 and in revised form 27 October

The Journal of Clinical Investigation, Inc.

Volume 79, February 1987, 473-477
Barbiturates are thought to produce their pharmacological effects at gamma-aminobutyric acid (GABA) ${ }^{1}$-gated chloride channels in the central nervous system (5-8). Barbiturates have been shown to enhance selectively the actions of GABA at concentrations corresponding to anticonvulsant, anxiolytic, and hypnotic doses, while at higher concentrations (corresponding to anesthetic/respiratory depressant doses) barbiturates depress neuronal excitability by directly increasing chloride conductance $(6,7)$. Biochemical studies suggest that barbiturates exert these effects at specific recognition sites located at or near GABAgated chloride channels. These so called "barbiturate receptors" (9) are allosterically linked to both $\mathrm{GABA}_{\mathrm{A}}$ and benzodiazepine receptors (9-16), and this family of allosterically linked recognition sites, the "supramolecular complex" (17), is presumed to mediate the pharmacological actions of many agents that alter neuronal excitability at GABA-gated chloride channels.

Recent advances in our understanding of the relationships between components of this "supramolecular complex" have led to the prediction (18) that benzodiazepine receptor ligands with full "inverse agonist" properties $(14,19,20)$ would antagonize those pharmacologic actions of barbiturates that are mediated through the supramolecular complex. We have tested this hypothesis by examining the effects of 6,7-dimethoxy-4-ethyl3 -carbomethoxy- $\beta$-carboline (DMCM) (a high affinity benzodiazepine receptor ligand with full inverse agonist properties) (19) in mice treated with a lethal dose of pentobarbital. We now report that DMCM significantly increases both the 1- and 24-h survival rates in these animals, and that this effect is mediated through a specific action at the benzodiazepine receptor component of the supramolecular complex. Since DMCM produces a significant reduction in the lethal effect of pentobarbital at doses that exhibit marginal toxicity, this compound or a related benzodiazepine receptor ligand with full inverse agonist properties may be potentially useful as an antidote against barbiturate poisoning in man.

\section{Methods}

Treatment protocols. Adult, male National Institutes of Health (NIH) mice (20-25 g) (Veterinary Resources Branch, NIH, Bethesda, MD) were used in all experiments. Sodium pentobarbital was administered at a dose $(135 \mathrm{mg} / \mathrm{kg})$ which was lethal to $>90 \%\left(\mathrm{LD}_{94}\right)$ of mice within 24 $h$. The lethal effects of pentobarbital were determined in mice that received no subsequent injections. Sodium pentobarbital was dissolved in $10 \%$ ethanol-20\% propylene glycol- $70 \%$ distilled water. Mice were injected

1. Abbreviations used in this paper: DMCM, 6,7-dimethoxy-4-ethyl-3carbomethoxy- $\beta$-carboline; GABA, gamma-aminobutyric acid; Ro $15-$ 1788, ethyl-8-fluoro-5,6-dihydro-5-methyl-6-oxo-4H-imidazo$[1,5 \mathrm{a}][1,4]$ benzodiazodiazepine-3-carboxylate. 
with $1.5-15 \mathrm{mg} / \mathrm{kg}$ of DMCM dissolved in $20 \%$ diluted emulphor-80\% saline (diluted emulphor is 50\% Emulphor [a polyoxyethylenated vegetable oil]-50\% ethanol wt/wt) $5 \mathrm{~min}$ after pentobarbital $(135 \mathrm{mg} / \mathrm{kg})$ administration. In some experiments, mice received an additional injection of DMCM or vehicle 60 min after pentobarbital. In studies to determine the toxic (convulsant and lethal) effects of DMCM, mice received two injections of drug 55 min apart. In experiments attempting to reverse the effects of DMCM, mice were injected with pentobarbital $(135 \mathrm{mg} / \mathrm{kg}$ ) and $2.5 \mathrm{~min}$ later received ethyl-8-fluoro-5,6-dihydro-5methyl-6-oxo-4H-imidazo[1,5a][1,4]benzodiazodiazepine-3-carboxylate (Ro $15-1788)(5 \mathrm{mg} / \mathrm{kg}$, dissolved in $20 \%$ diluted emulphor- $80 \%$ saline) or vehicle. DMCM $(5 \mathrm{mg} / \mathrm{kg})$ was administered $2.5 \mathrm{~min}$ later. The effects of drug treatments were assessed independently by two investigators. Cessation of respiration and the absence of a palpable heartbeat were used to evaluate the lethal actions of pentobarbital. All drugs were administered intraperitoneally in a volume of $0.1 \mathrm{ml}$. Multiple injections were administered alternatively to the left and right sides.

Statistics. The dose-effect curve of DMCM on 1-h survival was evaluated using Armitage's procedure (21), with Fisher's exact test (22) applied to animals receiving 10 and $15 \mathrm{mg} / \mathrm{kg}$ of drug. The 24-h survival was evaluated by first randomly apportioning the 1-h survivors to several treatment groups and then noting survival within each group at $24 \mathrm{~h}$. This subsampling of 1-h survivors generated the 24-h survival rate $(r)$ for a given treatment group. The 24-h survival rate $(r)=x y /(n m)$, where $n$ is the total number of animals; $x$ the number of $1-\mathrm{h}$ survivors; $m$ the number of 1-h survivors selected for a group; and $y$ the number of 24 $\mathrm{h}$ survivors in that group. The standard error of $r$ is derived as the square root of $\left(p_{1} p_{2} / n\right)\left[\left(1-p_{2}\right) / f+p_{2}\left(1-p_{1}\right)\right]$, where $p_{1}$ (estimated as $\left.x / n\right)$ is the probability of surviving $1 \mathrm{~h}, p_{2}$ (estimated by $y / m$ ) is the probability of surviving $24 \mathrm{~h}$ having survived $1 \mathrm{~h}$, and $f$ is the proportion of $1-\mathrm{h}$ survivors assigned to the group. The Bonferroni adjustment (23) was applied to the $P$ values obtained. The 24 -h survival rates for different treatment groups were compared under the assumption that their statistical distributions were approximately normal. This procedure was used to avoid overestimating the 24-h survival rates, which should account for the overall mortality (i.e., the survival rate at both 1 and $24 \mathrm{~h}$ ).

Materials. DMCM was purchased from Research Biochemical, Wayland, MA. Sodium pentobarbital was purchased from Sigma Chemical Co., St. Louis, MO. Ro 15-1788 was donated by Hoffman-LaRoche, Inc., Nutley, NJ. Emulphor was the gift of GAF Corp. New York, NY.

\section{Results}

Pentobarbital lethality: effects of DMCM administration. Administration of $135 \mathrm{mg} / \mathrm{kg}$ sodium pentobarbital was lethal to $87 \%$ of the mice within $1 \mathrm{~h}$ (Fig. 1). Within $5 \mathrm{~min}$ after injection, mice were unresponsive to tail pressure and had lost the righting reflex. These animals also showed signs of profound respiratory distress characterized by infrequent and irregular breathing. DMCM $(1.5-5 \mathrm{mg} / \mathrm{kg})$ produced a dose-dependent increase in survival at $60 \mathrm{~min}(P<0.001)$ with an optimum survival rate of $68 \%$ (Fig. 1). Significant increases in 1-h survival were also observed in mice treated with 10 or $15 \mathrm{mg} / \mathrm{kg}$ of DMCM $(P$ $<0.001$ and $P<0.002$ ), but these values were not significantly different from that with the $5-\mathrm{mg} / \mathrm{kg}$ dose of DMCM (Fig. 1).

Mice that received DMCM $(2.5-10 \mathrm{mg} / \mathrm{kg}) 5 \mathrm{~min}$ after pentobarbital were subsequently divided into three groups: the first group was administered a second injection of DMCM vehicle, while the second and third groups, which had initially received the optimum dose of DMCM $(5 \mathrm{mg} / \mathrm{kg})$, were administered a second injection of either 2.5 or $5 \mathrm{mg} / \mathrm{kg}$ of DMCM $1 \mathrm{~h}$ after pentobarbital. The mice were then returned to their home cages for evaluation of 24-h survival. The 24-h survival rate in mice treated only with pentobarbital was 6\% (Fig. 2). DMCM (2.5 $\mathrm{mg} / \mathrm{kg}$ ), followed $1 \mathrm{~h}$ later by vehicle, did not improve overall

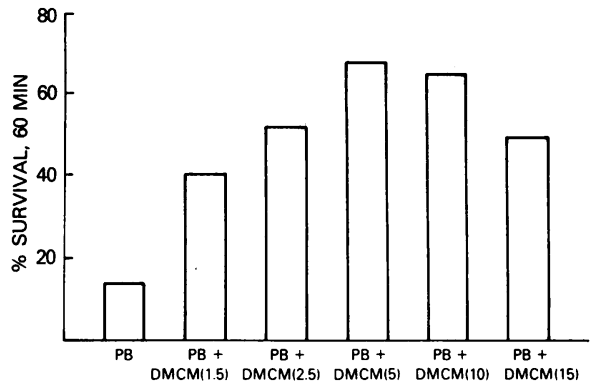

Figure 1. Effects of DMCM on pentobarbital (PB) lethality: 1-h survival. Mice were injected with $P B(135 \mathrm{mg} / \mathrm{kg}) .5 \mathrm{~min}$ later they were injected with DMCM $(1.5-15 \mathrm{mg} / \mathrm{kg})$ and the number of animals alive at $60 \mathrm{~min}$ was determined as described in Methods. Animals receiving $P B$ alone did not receive an additional injection at $5 \mathrm{~min}$. The number of animals used to determine percent survival in each group was: PB, 94; PB + DMCM, $1.5 \mathrm{mg} / \mathrm{kg}, 20 ;$ PB + DMCM, $2.5 \mathrm{mg} / \mathrm{kg}$, 54; $\mathrm{PB}+\mathrm{DMCM}, 5 \mathrm{mg} / \mathrm{kg}, 50 ; \mathrm{PB}+\mathrm{DMCM}, 10 \mathrm{mg} / \mathrm{kg}, 55$; and PB + DMCM, $15 \mathrm{mg} / \mathrm{kg}, 20$. The proportion of animals surviving after DMCM increased in a linear fashion $(P<0.001)(21)$ between 1.5 and $5 \mathrm{mg} / \mathrm{kg}$. Statistically significant increases survival were also observed at $10(P<0.001)$ and $15(P<0.002) \mathrm{mg} / \mathrm{kg}$ of DMCM.

survival at $24 \mathrm{~h}$ (Fig. 2). However, pentobarbital-treated mice that received 5 or $10 \mathrm{mg} / \mathrm{kg}$ of DMCM and an injection of vehicle 55 min later had significantly higher 24 -h survival rates $(34 \%$, $P<0.006$, and 33\%, $P<0.008$, respectively) than mice treated with pentobarbital alone (Fig. 2). Injection of $5 \mathrm{mg} / \mathrm{kg}$ of DMCM followed by $2.5 \mathrm{mg} / \mathrm{kg} 55 \mathrm{~min}$ later resulted in a further im-

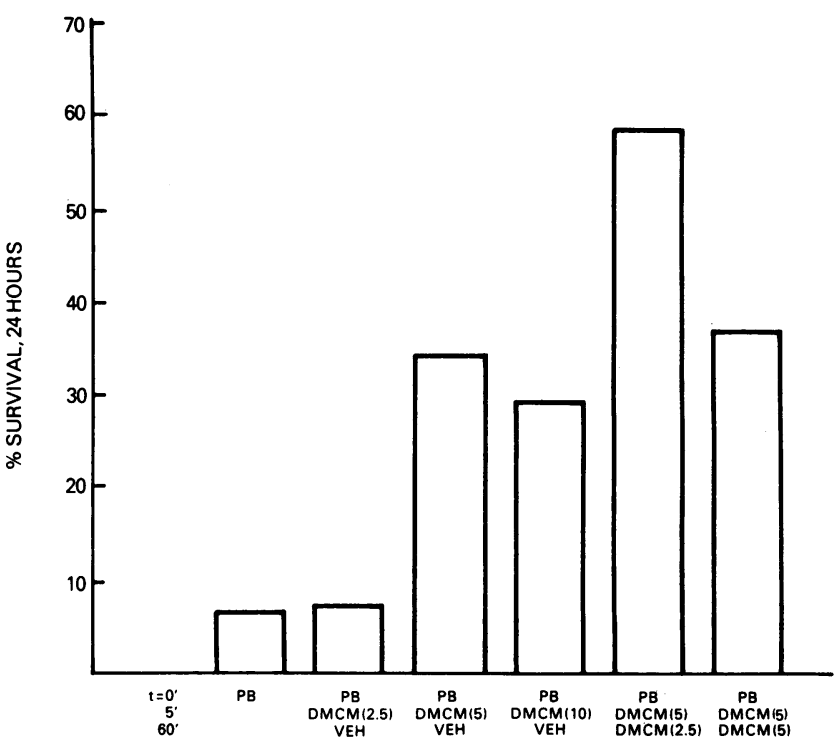

Figure 2. Effects of DMCM on pentobarbital (PB) lethality: 24-h survival. Mice that survived for $1 \mathrm{~h}$ after receiving a combination of $\mathrm{PB}$ and DMCM (see Fig. 1) were injected with vehicle or DMCM as indicated. Animals receiving $\mathrm{PB}$ alone did not receive additional injections. The efficacy of the different treatment protocols was evaluated as described in Methods using Bonferroni's adjustment for the $\boldsymbol{P}$ values. Thus, in order to maintain alpha at $<0.05$, comparisons are significant if $P<0.05 / 5=0.01$. PB vs. PB + DMCM $(2.5 \mathrm{mg} / \mathrm{kg})+$ vehicle $(\mathrm{V})=0.034$; vs. PB + DMCM ( $5 \mathrm{mg} / \mathrm{kg})+\mathrm{V}=0.006$; vs. PB $+\mathrm{DMCM}(10 \mathrm{mg} / \mathrm{kg})+\mathrm{V}=0.008 ; \mathrm{vs} . \mathrm{PB}+\mathrm{DMCM}(5 \mathrm{mg} / \mathrm{kg})$ + DMCM $(2.5 \mathrm{mg} / \mathrm{kg})<0.001 ;$ vs. PB + DMCM $(5 \mathrm{mg} / \mathrm{kg})$

$+\operatorname{DMCM}(5 \mathrm{mg} / \mathrm{kg})=0.004$ 
provement of 24 -h survival rates $(58.3 \%, P<0.001)$. The 24 -h survival rate of mice that received a second $5 \mathrm{mg} / \mathrm{kg}$ injection of DMCM was significantly higher than animals that did not receive DMCM $(36.6 \%, P<0.004)$ (Fig. 2$)$.

In another series of experiments, the protective effect of DMCM $(5 \mathrm{mg} / \mathrm{kg})$ in pentobarbital-treated mice was examined in the presence of the benzodiazepine receptor antagonist, Ro $15-1788$ (24). Ro $15-1788(5 \mathrm{mg} / \mathrm{kg})$ completely abolished the protective effects of DMCM (from 65 to $0 \%$ survival at $1 \mathrm{~h}$ ) when administered 2.5 min before DMCM (Fig. 3).

Toxicity of DMCM. The toxic (convulsant and lethal) effects of DMCM were examined in a dose range that reduced the lethal effect of pentobarbital. At a dose of $2.5 \mathrm{mg} / \mathrm{kg}$ DMCM did not elicit convulsions, nor were any deaths noted during the 1-h observation period. A second injection of $2.5 \mathrm{mg} / \mathrm{kg}$ of DMCM $55 \mathrm{~min}$ after the initial dose did not result in either convulsions or deaths (Fig. 4). Administration of 5 and $10 \mathrm{mg} / \mathrm{kg}$ of DMCM produced convulsions in 6 and $94 \%$ of the animals, respectively. The $50 \%$ convulsion dose $\left(\mathrm{CD}_{50}\right)$ of $\mathrm{DMCM}$ was estimated to be $7.5 \mathrm{mg} / \mathrm{kg}$ (Fig. 4 legend). The latency to convulsions in these animals was $<15 \mathrm{~min}$ (data not shown). A second injection of 5 or $10 \mathrm{mg} / \mathrm{kg}$ of DMCM did not produce a significant further increase the incidence of convulsions (Fig. 4). Deaths were observed only at the $10-\mathrm{mg} / \mathrm{kg}$ dose, with a $15 \%$ mortality noted after one injection, and an overall mortality of $20 \%$ in mice receiving a second injection of $10 \mathrm{mg} / \mathrm{kg}$ DMCM (data not shown).

\section{Discussion}

An effective, safe antidote for severe barbiturate intoxication would be an important therapeutic adjunct in emergency medicine. Recent studies on benzodiazepine/GABA receptor chloride ionophore complex suggested that a benzodiazepine receptor ligand with full inverse agonist properties would antagonize the lethal effects of barbiturates (18). We examined this hypothesis in experimental animals by administering the inverse agonist DMCM to mice that received a lethal dose $(135 \mathrm{mg} / \mathrm{kg})$ of pentobarbital (approximately $\mathrm{LD}_{94}$ ). In an attempt to mimic conditions which could be encountered in a clinical situation, DMCM was administered to animals that were comatose and unresponsive to external stimuli. Under these conditions, dosedependent increases in both 1- and 24-h survival were observed after a single injection of DMCM; the maximum survival rate was more than five times that observed in animals receiving pentobarbital alone (Figs. 1 and 2). The overall survival at $24 \mathrm{~h}$ was further increased by administration of a divided dose of

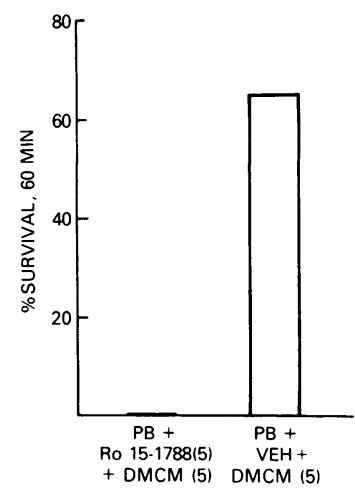

Figure 3. Antagonism of the protective effects of DMCM by Ro 15-1788. Mice were injected with pentobarbital (PB) $(135 \mathrm{mg} / \mathrm{kg})$. Ro $15-1788(5 \mathrm{mg} /$ $\mathrm{kg})$ or vehicle $(0.1 \mathrm{ml}$ of $20 \%$ diluted Emulphor $/ 80 \%$ saline) was injected $2.5 \mathrm{~min}$ later. DMCM $(5 \mathrm{mg} / \mathrm{kg})$ was injected $2.5 \mathrm{~min}$ after the Ro 15-1788. 20 animals were used in each group.

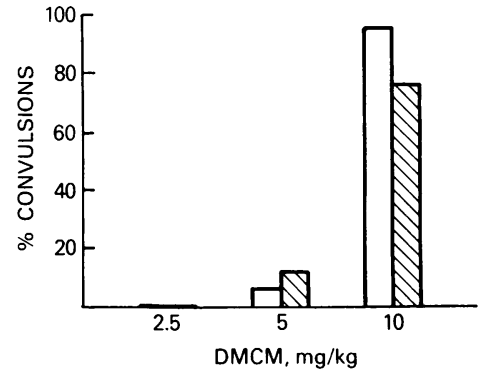

Figure 4. Toxicity of DMCM. Naive mice were injected with $2.5-10 \mathrm{mg} /$ $\mathrm{kg}$ of DMCM. The percentage of animals having clonic and/or tonic convulsions was noted. (Open bars) Single injection of DMCM. (Hatched bars) Percentage of animals with convulsions after a

second injection 55 min later. 20 animals were used in each group. Deaths were observed only after the highest dose of DMCM; the mortality was 15 and $20 \%$ after one and two injections of DMCM, respectively.

DMCM (Fig. 2), which suggests that an alternative means of drug delivery (e.g., infusion or multiple dosing) might prove even more effective in reducing mortality. Nonetheless, the different pharmacokinetic (1) and pharmacodynamic $(5,25,26)$ properties of the various barbiturates requires further testing of DMCM before optimum doses and routes of administration can be assigned.

Electrophysiological and biochemical studies suggest that barbiturates, as well as compounds such as pentylenetetrazole and picrotoxin (that have been used as barbiturate antidoes) (4) bind to closely associated recognition sites on the GABA-gated chloride channel $(6,7,13,27-29)$. However, the doses of pentylenetetrazole and picrotoxin or related "cage" convulsants (30) that reduce barbiturate lethality also produce a high incidence of convulsions and deaths at the same doses when administered alone. In these concentrations, compounds such as picrotoxin and pentylenetetrazole presumably inhibit the binding of barbiturates to their recognition sites, "closing" GABA-gated chloride channels. By contrast, DMCM has been shown to reduce GABA-gated chloride conductance through occupation of benzodiazepine receptors (31). The observation that pretreatment of animals with the benzodiazepine receptor antagonist Ro 151788 can antagonize the effects of DMCM in reducing pentobarbital lethality supports this hypothesis (Fig. 3). Since DMCM does not bind to the same recognition sites as barbiturates, it is unlikely that DMCM can affect chloride currents at channels exposed to high (anesthetic/lethal) concentrations of pentobarbital that have a direct effect on chloride currents $(6,7)$. However, since DMCM reduces GABA-gated chloride currents (31), it will affect those channels exposed to concentrations of pentobarbital sufficient to augment GABA-gated chloride currents (6, 7). Thus, DMCM may “normalize" chloride currents at the latter population of channels (18), thereby reducing lethality. While this hypothesis has not been fully tested, recent reports on the effects of partial inverse agonists such as 3-hydroxymethyl- $\beta$ carboline $(32,33)$ and CGS $8216(34)$ on other pharmacologic properties of pentobarbital support this hypothesis.

DMCM is more efficacious and less toxic than other putative barbiturate antidotes such as picrotoxin (see reference 30 ). A single injection of a nonlethal $\left(C_{6}\right)$ dose of DMCM $(5 \mathrm{mg} / \mathrm{kg})$ increased 1- and 24-h survival rates approximately fivefold (Figs. 1 and 2), while administration of a second dose of DMCM (2.5 $\mathrm{mg} / \mathrm{kg}$ ) $55 \mathrm{~min}$ later increased 24-h survival more than ninefold compared with pentobarbital alone (Fig. 2). Nonetheless, DMCM is a convulsant, and lethal at sufficiently high doses (reference 35, and Fig. 4 legend). While the effects of DMCM have not 
been evaluated in man, this compound is likely to have a pharmacologic profile similar to that observed in rodents which could potentially limit its usefulness as an antidote. However, Ro 151788 (which by itself does not antagonize the effects of barbiturates [reference 24 and Fig. 3]) completely blocks the effects of DMCM (Fig. 3). Thus, it is likely that Ro 15-1788, which has already been shown to be an effective benzodiazepine antagonist in man $(36,37)$, could be used to reverse any adverse effects of DMCM without further compromising a barbiturate-intoxicated patient. DMCM may also be effective in cases where a combination of barbiturates and benzodiazepines has been ingested, since $\beta$-carbolines with inverse agonist properties can also antagonize the pharmacologic actions of benzodiazepines (33, 38,39 ).

Recent evidence suggests that ethanol may produce its intoxicating and sedative actions by perturbing membrane fluidity at the supramolecular complex (40). A novel imidazobenzodiazepine, Ro $15-4513(41,42)$, has been shown to antagonize the pharmacologic actions of ethanol $(41,42)$, but does not appear to antagonize the pharmacologic effects of barbiturates (42). Thus, a combination of Ro 15-4513 (or a related compound) and DMCM could be potentially useful as an antidote in cases where a combination of ethanol and barbiturates are ingested. This hypothesis is currently under investigation.

\section{Acknowledgments}

The authors thank K. Armstrong and B. Jackson for technical assistance. Dr. Havoundjian was a Howard Hughes Medical Research Scholar during these studies.

\section{References}

1. Harvey, S. 1975. Hypnotics and sedatives. In The Pharmacological Basis of Therapeutics. 5th edition. L. Goodman and A. Gilman, editors. MacMillan Publishing Co., New York. 102-123.

2. Victor, M., and R. Adams. 1983. Sedatives, stimulants, and psychotropic drugs. In Harrison's Principles of Internal Medicine. R. Petersdorf, R. Adams, E. Braunwald, K. Isselbacher, J. Martin, and J. Wilson, editors. McGraw-Hill, Inc., New York. 1295-1352.

3. Winchester, J. 1983. Barbiturates. In Clinical Management of Poisoning and Drug Overdose. L. Haddad and J. Winchester, editors. W. B. Saunders, Co., Philadelphia. 413-424.

4. Hahn, F. 1960. Analeptics. Pharmacol. Rev. 12:447-530.

5. MacDonald, R., and J. Barker. 1978. Different actions of anticonvulsant and anesthetic barbiturates revealed by use of cultured mammalian neurons. Science (Wash. DC). 200:775-777.

6. Nicoll, R., and J. Wojtowicz. 1980. The effects of pentobarbital and related compounds on frog motoneurons. Brain Res. 191:225-237.

7. Schulz, D., and R. MacDonald. 1981. Barbiturate enhancement of GABA-mediated inhibition and activation of chloride ion conductance: correlation with anticonvulsant and anesthetic actions. Brain Res. 209: 177-188.

8. Study, R., and J. Barker. 1981. Diazepam and (-)-pentobarbital: fluctuation analysis reveals different mechanisms for potentiation of $\gamma$ aminobutyric acid responses in cultured central neurons. Proc. Natl. Acad. Sci. USA. 78:7180-7184.

9. Leeb-Lundberg, F., A. Snowman, and R. Olsen. 1980. Barbiturate receptor sites are coupled to benzodiazepine receptors. Proc. Natl. Acad. Sci. USA. 77:7486-7472.

10. Skolnick, P., S. Paul, and J. Barker. 1980. Pentobarbital potentiates GABA-enhanced $\left[{ }^{3} \mathrm{H}\right]$ diazepam binding to benzodiazepine receptors. Eur. J. Pharmacol. 65:125-127.

11. Skolnick, P., V. Moncada, J. Barker, and S. Paul. 1981. Pento- barbital has dual actions to increase brain benzodiazepine receptor affinity. Science (Wash. DC). 211:1448-1450.

12. Paul, S., P. Maranagos, and P. Skolnick. 1981. The benzodiazepine-GABA-chloride ionophore receptor complex: common site of minor tranquilizer action. Biol. Psychiatry 16:213-229.

13. Squires, R., J. Casida, M. Richardson, and E. Saederup. 1983. $\left[{ }^{35} \mathrm{~S}\right] \mathrm{t}$-butylbicyclophosphorothionate binds with high affinity to brain specific sites coupled to $\gamma$-aminobutyric acid-A and ion recognition sites. Mol. Pharmacol. 23:326-336.

14. Karobath, M., P. Supavilai, and P. Borea. 1983. Distinction of benzodiazepine receptor agonists and inverse agonists by binding studies in vitro. In Benzodiazepine Recognition Site Ligands: Biochemistry and Pharmacology. G. Biggio and E. Costa, editors. Raven Press, New York. $37-45$.

15. Supavilai, P., and M. Karobath. 1984. $\left[{ }^{35}\right.$ S $]$ t-butylbicyclophosphorothionate binding sites are constituents of the $\boldsymbol{\gamma}$-aminobutyric acid benzodiazepine receptor complex. J. Neurosci. 4:1193-1200.

16. Schwartz, R., J. Jackson, D. Weigert, P. Skolnick, and S. Paul. 1985. Characterization of barbiturate-stimulated chloride efflux from rat brain synaptoneurosomes. J. Neurosci. 5:2963-2970.

17. Tallman, J., S. Paul, P. Skolnick, and D. Gallager. 1980. Receptors for an age of anxiety: molecular pharmacology of the benzodiazepines. Science (Wash. DC). 207:274-281.

18. Skolnick, P., H. Havoundjian, and S. Paul. 1986. Modulation of the benzodiazepine-GABA receptor complex by multiple, allosteric sites: evidence for a barbiturate receptor. In Clinical Pharmacology in Psychiatry. S. Dahl, L. Gram, S. Paul, and W. Potter, editors. SpringerVerlag, Berlin. In press.

19. Braestrup, C., M. Nielsen, T. Honoré, L. Jensen, and E. Petersen. 1983. Benzodiazepine receptor ligands with positive and negative efficacy. Neuropharmacology. 22:1451-1457.

20. Haefely, W., E. Kyburz, M. Gerecke, and H. Mohler. 1985. Recent advances in the molecular pharmacology of benzodiazepine receptors and in the structure-activity relationships of their agonists and antagonists. In Advances in Drug Research. B. Testa, editor. Academic Press, London. 166-322.

21. Armitage, P. 1959. Tests for linear trends in proportions and frequencies. Biometrics. 11:375-386.

22. Fleiss, J. 1980. Statistical Methods for Rates and Proportions. 2nd edition. J. Wiley \& Sons, New York. 1-321.

23. Miller, R. 1980. Simultaneous Statistical Inference. 2nd edition. Springer-Verlag, New York. 1-299.

24. Hunkeler, W., H. Mohler, L. Pieri, P. Polc, E. Bonetti, R. Cumin, R. Schaffner, and W. Haefely. 1981. Selective antagonists of benzodiazepines. Nature (Lond.). 290:514-516.

25. Leeb-Lundberg, F., and R. Olsen. 1982. Interactions of barbiturates of various pharmacological categories with benzodiazepine receptors. Mol. Pharmacol. 21:320-328.

26. Skolnick, P., K. Rice, J. Barker, and S. Paul. 1982. Interaction of barbiturates with benzodiazepine receptors in the central nervous system. Brain Res. 233:143-156.

27. Pellmar, T., and W. Wilson. 1977. Synaptic mechanism of pentylenetetrazole: selectivity for chloride conductance. Science (Wash. DC). 197:912-914.

28. Squires, R., E. Saederup, J. Crawley, P. Skolnick, and S. Paul. 1985. Convulsant potencies of tetrazoles are highly correlated with actions on GABA/benzodiazepine/picrotoxin receptor complexes in brain. Life Sci. 35:1454-1459.

29. Ramanjaneyulu, R., and M. Ticku. 1984. Binding characteristics and interactions of depressant drugs with $\left[{ }^{35}\right.$ S]t-butylbicyclophosphorothionate, a ligand that binds to the picrotoxinin site. J. Neurochem. 42:221-229.

30. Mendelson, W., J. Martin, R. Wagner, C. Roseberry, P. Skolnick, B. Weissman, and R. Squires. 1985. Are the toxicities of pentobarbital and ethanol mediated by the GABA-benzodiazepine receptor-chloride ionophore complex? Eur. J. Pharmacol. 108:63-70.

31. Chan, C., and D. Farb. 1985. Modulation of neurotransmitter 
action: control of the $\gamma$-aminobutyric acid response through the benzodiazepine receptor. J. Neurosci. 5:2365-2372.

32. Albrechtsen, R., J. Cook, E. Hoffman, P. Larscheid, D. Miletich, and $\mathrm{N}$. Naughton. 1985. The interaction between benzodiazepine antagonists and barbiturate-induced cerebrovascular and cerebral metabolic depression. Neuropharmacology. 24:957-963.

33. Mendelson, W., M. Cain, J. Cook, S. Paul, and P. Skolnick. 1983. A benzodiazepine receptor antagonist decreases sleep and reverses the hypnotic actions of flurazepam. Science (Wash. DC). 219:414-415.

34. Mendelson, W., T. Davis, S. Paul, and P. Skolnick. 1983. Do benzodiazepine receptors mediate the anticonflict actions of pentobarbital? Life Sci. 32:2241-2246.

35. Braestrup, C., R. Schmiechen, G. Neff, M. Nielsen, and E. Petersen. 1982. Interaction of convulsive ligands with benzodiazepine receptors. Science (Wash. DC). 216:1241-1243.

36. Darragh, A., R. Lambe, M. Kenny, I. Brick, W. Taaffe, and C. O'Boyle. 1982. Ro 15-1788 antagonizes the central effects of diazepam in man without alterating diazepam bioavailability. Br. J. Clin. Pharmacol. 14:677-682.
37. Darragh, A., M. Scully, R. Lambe, I. Brick, C. O'Boyle, and W. Downie. 1981. Investigation in man of the efficacy of a benzodiazepine antagonist, Ro 15-1788. Lancet. ii:8-10.

38. Tenen, S., and J. Hirsch. 1980. B-Carboline-3-carboxylic acid ethyl ester antagonizes diazepam activity. Nature (Lond.). 288:609-610.

39. Cowen, P., A. Green, D. Nutt, and I. Martin. 1981. Ethyl-Bcarboline carboxylate lowers seizure threshold and antagonizes flurazepam-induced sedation in rats. Nature (Lond.). 290:54-55.

40. Sudzak, P., R. Schwartz, P. Skolnick, and S. Paul. 1986. Ethanol stimulates $\gamma$-aminobutyric acid receptor-mediated chloride transport in rat brain synaptoneurosomes. Proc. Soc. Natl. Acad. Sci. USA. 83:40714075.

41. Bonetti, E., W. Burkard, M. Gabl, and H. Mohler. 1985. The partial inverse benzodiazepine agonist Ro 15-1413 antagonizes acute ethanol effects in rats and mice. Br. J. Pharmacol. 86:463P.

42. Polc, P. 1985. Interactions of partial inverse benzodiazepine agonists Ro 15-4513 and FG 7142 with ethanol in rats and cats. $B r$. $J$. Pharmacol. 86:465P. 